\title{
ADIPOR2 wt Allele
}

National Cancer Institute

\section{Source}

National Cancer Institute. ADIPOR2 wt Allele. NCI Thesaurus. Code C103977.

Human ADIPOR2 wild-type allele is located in the vicinity of 12p13.31 and is approximately $100 \mathrm{~kb}$ in length. This allele, which encodes adiponectin receptor protein 2 , is involved in hormone-mediated signaling. 